Research Report No. 37/2009

\title{
Hanse Law School - A Promising Example of Transnational Legal Education?: An Alumna's Perspective
}

Franziska Weber

Follow this and additional works at: http:/ / digitalcommons.osgoode.yorku.ca/clpe

\section{Recommended Citation}

Weber, Franziska, "Hanse Law School - A Promising Example of Transnational Legal Education?: An Alumna's Perspective" (2009). Comparative Research in Law \& Political Economy. Research Paper No. 37/2009.

http://digitalcommons.osgoode.yorku.ca/clpe/149 


\section{Comparative Research in Law \& Political Economy}

\section{Franziska Weber}

\section{Hanse Law School - A Promising Example of Transnational Legal Education? An Alumna's Perspective}

EDITORS: Peer Zumbansen (Osgoode Hall Law School, Toronto, Director, Comparative Research in Law and Political Economy, York University), John W. Cioffi (University of California at Riverside), Nassim Nasser (Osgoode Hall Law School, Toronto, Production Editor)

Also available at: http: / /www.germanlawjournal.com 



\section{German Law Journal}

Hanse Law School - A Promising Example of Transnational Legal Education? An Alumna's Perspective Franziska Weber

10 German Law Journal 785 (2009), available at:

http://www.germanlawjournal.com/article.php?id=1133

This article was originally published in Volume 10, Number 7 of the German Law Journal as part of the journal's $10^{\text {th }}$ anniversary symposium on "Transnationalizing Legal Education" edited by Nadia Chiesa, Adam de Luca, and Bernadette Maheandiran. 
CLPE Research Paper 37/2009

Vol. 05 No. 06(2009)

\title{
Franziska Weber
}

\section{Hanse Law School - A Promising Example of Transnational Legal Education? Alumna's Perspective}

\begin{abstract}
Many years after the Bologna declaration a possible reform of the German legal system is still hotly debated. Already 6 years ago the Universities of Bremen, Oldenburg and Groningen introduced a Bachelor/Master programme in European and Comparative Law (Hanse Law School). This contribution shall illustrate in how far these programmes meet new demands of the internationalised labour market. To achieve this the content and the aim of the programmes shall be contrasted with the traditional German legal education and reactions that graduates experienced on the labour market shall be analysed. What can be a promising way for universities to adjust their way of skilling to contemporary challenges? Are the students and graduates of the Hanse Law School, for example, experiencing that the study is "fortiter in re, suaviter in modo" as the slogan advertises and for what kind of career are they equipped?
\end{abstract}

Keywords: Legal education, Transnational legal education

JEL classification: K10, K40

Franziska Weber

LL.M. graduated from the Hanse Law School (LL.B.) in September 2006.

She is currently a PhD. candidate at the Rotterdam Institute of Law and Economics (RILE).

Email: mailto:f.weber@frg.eur.nl. 



\title{
SPECIAL ISSUE: TRANSNATIONALIZING LEGAL EDUCATION
}

\section{'Hanse Law School' - A Promising Example of Transnational Legal Education? An Alumna's Perspective}

\author{
By Franziska Weber*
}

\section{A. Introduction}

Starting with the European Coal and Steel Community in $1951^{1}$ and the establishment of the European Economic Community by the Treaty of Rome in $1957^{2}$ with only 6 member states, ${ }^{3}$ Europe has since become a political and economic union of 27 Member States that has wide law-making competences and thus considerably affects daily life in Europe. ${ }^{4}$ With the overall aim of creating a common market for economic activities, borders are largely disappearing and people are free to travel to other Member States and stay, study or work.

The European Union (EU) also has its own court - the European Court of Justice (ECJ) - that watches over the uniform and effective application of European Law across the Member States. ${ }^{5}$ The body of European Law, which is an own legal order besides the national laws, is increasing. Its source of inspiration lies in comparative studies of the laws of the Member States. Therefore, not only European, but also Comparative Law should be a crucial part of the curricula of national law programs. Transnational legal education is indispensable for the attainment of the skills to engage in successful legal comparisons, and in the making and application of European Law.

\footnotetext{
* Franziska Weber LL.M. graduated from the Hanse Law School (LL.B.) in September 2006. She is currently a Ph.D. candidate at the Rotterdam Institute of Law and Economics (RILE). Email: f.weber@frg.eur.nl.

1 See, "Declaration of 9 May 1950" EUROPEAN COMmISSION, available at: http://europa.eu/abc/symbols/9may/decl_en.htm, last accessed, 20 May 2009.

${ }^{2}$ The Treaties of Rome, 25 March 1957, are two of the treaties of the European Union: the first established the European Economic Community (EEC) and the second established the European Atomic Energy Community (EAEC or EURATOM). Later on these treaties have been amended and renamed several times.

${ }^{3}$ Belgium, France, Italy, Luxembourg, the Netherlands and West Germany.

${ }^{4}$ The EU is unique in being a 'supranational' entity that is characterized by the fact that Member States have voluntarily agreed to transfer originally national legislative competences to the higher entity, see the groundbreaking Case 26/62, Van Gend and Loos, 1963 E.C.R. 1, para. 12 where the Court held that 'the Community constitutes a new legal order of international law for the benefit of which the States have limited their sovereign rights, albeit within limited fields...'

${ }^{5}$ See, CURIA - Court of Justice of the European Communities, available at: http://curia.europa.eu/jcms/jcms/ Jo1_6308/ecran-d-accueil, last accessed, 20 May 2009.
} 
In the ambit of facilitating student mobility - we have recently celebrated 20 years of Erasmus $^{6}-29^{7}$ European Ministers of Education in 1999 jointly declared to construct a European area of higher education by 2010 with the Bologna Declaration, ${ }^{8}$ foremost characterized by easily readable and comparable degrees, and a uniform grading system. Many years after the Bologna declaration, large parts of the German university landscape have been changed to the Bachelors and Masters structure ${ }^{9}$ - as in the majority of signatory states - but a reform of the German legal system is still hotly debated. ${ }^{10}$ Transnationalising legal education is particularly crucial due to the essential part that law obviously plays in shaping the EU and its activities.

In anticipation of Bologna-type reforms, the Universities of Bremen and Oldenburg in Germany and Groningen in the North of the Netherlands introduced, in 2002, a joint Bachelors/Masters program in European and Comparative Law that is known as the Hanse Law School. ${ }^{11}$ This article considers the extent to which this effort meets the demands of

\footnotetext{
${ }^{6}$ See, 20 Years Erasmus Programme - Erasmus Days Around Europe, available at: http://www.20erasmus.eu/ erasmusdays/view, last accessed, 20 May 2009. 'Erasmus' is a program that facilitates students' mobility by enabling them to spend a semester at another European university without having to pay tuition fees, with a guaranteed recognition of the courses taken at the foreign university and other advantages.
}

${ }^{7}$ These countries were Austria, Belgium, Bulgaria, Czech Republic, Denmark, Estonia, Finland, France, Germany, Greece, Hungary, Iceland, Ireland, Italy, Latvia, Lithuania, Luxembourg, Malta, the Netherlands, Norway, Poland, Portugal, Romania, Slovak Republic, Slovenia, Spain, Sweden, Switzerland, and the United Kingdom.

8 Please access the text of the declaration available at: http://www.bologna-berlin2003.de/pdf/ bologna_declaration.pdf, last accessed, 20 May 2009. The declaration is not a product of the EU or European Community (EC) and therefore limited in its binding legal character. The number of signatures has in the meantime increased: Croatia, Cyprus, Liechtenstein, Turkey (2001); Albania, Andorra, Bosnia and Herzegovina, the Holy See, Russia, Serbia, "the former Yugoslav Republic of Macedonia" (2003); Armenia, Azerbaijan, Georgia, Moldova and Ukraine (2005); and Montenegro (2007) joined which adds up to 46. See also, Hildegard Schneider \& Sjoerd Claessens, The Recognition of Diplomas and the Free Movement of Professionals in the European Union: Fifty Years of Experience (2007), available at http://www.ialsnet.org/meetings/assembly/HildegardSchneider.pdf, last accessed, 20 May 2009.

${ }^{9}$ For the regulation of the German universities see, 'Hochschulrahmengesetz', http://bundesrecht.juris.de/ bundesrecht/hrg/gesamt.pdf (in German), last accessed, 21 May 2009.

10 See the official website of the Bologna process, available at: http://www.ond.vlaanderen.be/ hogeronderwijs/bologna/, last accessed, 20 May 2009; alternatively information provided by the German Federal Ministry of Education and Research, available at: http://www.bmbf.de/de/3336.php, last accessed, 21 May 2009.

${ }^{11}$ For more information, see, Hanse Law School, available at: http://www.hanse-law-school.de/, last accessed, 21 May 2009. HLS was not even the first Bachelor - in Greifswald in 2000 an LL.B. was introduced, see, 'Wieder einmal die Nase vorn: erster deutscher Jura-Bachelor - (LL.B.) - Studiengang in Greifswald,' available at: http://www.uni-protokolle.de/nachrichten/id/62664/, last accessed, 20 May 2009; another LL.B. study is offered at the Bucerius Law School in Hamburg, see, Jurastudium: Bucerius Law School, available at: http://www.lawschool.de/jurastudium.html?\&L=0, last accessed, 20 May 2009. The Bachelors program there is, however, merely a first step on the way to completing the Staatsexam. Another Bachelors program integrated in the Staatsexam was recently set up in Mannheim: see, Carsten Schäfer, 'Bologna' in der Juristenausbildung? - Das Mannheimer Modell eines LL.B.-Studiengangs' in NEUE JURISTISCHE WOCHENSCHRIFT (NJW), 2487-2490 (2008). Conferring with a list 
the internationalising labour market, and does so particularly in the context of the Europeanisation of law in the European space. The content and aim of these programs are contrasted with the traditional German legal education as graduates are asked for their experiences in the labour market following graduation. ${ }^{12}$ How can universities best prepare their student for contemporary legal challenges and does the Hanse Law School succeed in equipping students for the careers that they seek? As the program is still very new this article only describes some initial reflections.

\section{B. The Traditional German Legal Education}

A Staatsexam (state examination) program in Germany prepares students primarily for entrance to service on the Bench. It follows the system of the Einheitsjurist (uniform jurist). ${ }^{13}$ There is no difference in formal qualifications in being admitted to the Bar or to the Bench. This is generally structured as follows ${ }^{14}$ : on average students apply to be admitted to the final examination after around ten semesters. ${ }^{15}$ Prior to taking the exam, there is the Repetitorium (revision course) (at least 1 year) that repeats all of what the students had learnt thus far and prepares them for the First State Exam - an exam, first written and then oral - that tests knowledge in the traditional three fields of law (civil, public and criminal law). Passing this exam allows for the admission to the Rechtsreferendariat (court traineeship) in which in ca. 2 years the Rechtsreferendar (law clerk) are trained in different legal areas in various posts (e.g. at the court). At the end of this period there will be another exam: the Second State Exam. During the study time an internship of 3 months is obligatory. Only recently legal terminology courses were made compulsory as were courses on key skills, e.g. mediation or negotiation. An increasing

of other possible LL.B.'s and their curricula it becomes obvious that the focus of the HLS is unique, Bachelor of Laws - Wikipedia, available at: http://de.wikipedia.org/wiki/Bachelor_of_Laws, last accessed, 20 May 2009.

12 Please consider that the program started in 2002/03 and that three classes had already obtained their LL.M. and thus four classes had achieved their LL.B. Throughout the paper, I will refer to a survey 'Facts \& Figures' that was carried out in 2007. The judgments that I will make are my personal opinion. They were, however, enriched by discussions with and emails to former fellow students from 2002 to 2004.

${ }^{13}$ See, Annette Keilmann, The Einheitsjurist - A German Phenomenon, 7 German LAW JournaL (GLJ), No. 3, 293 312 (2006), available at: http://www.germanlawjournal.com/article.php?id=712, last accessed, 20 May 2009 . The concept entails that every law student has to follow the same legal education independent of the legal professions he/she aims at.

${ }^{14}$ I shall not go into details about the structure of the Staatsexam as it depends to a certain extent on the Bundesland (state) what the details look like. See homepage of the Federal Ministry of Justice, available at: http://www.bmj.bund.de/enid/1ae551402344f8412736d5f791bce952,0/Rechtspflege/Juristische_Aus-

_und_Fortbildung_16i.html (Federal Ministry of Justice), last accessed, 21 May 2009. However there are general principles in the form of federal legislation.

15 See statistics by the German Federal Ministry of Justice with most recent data from 2006, available at: http://www.bmj.bund.de/files/-/2457/Ausbildungsstatistik_2006.pdf, last accessed, 21 May 2009. 
number of students opt for the Freiversuch (free trial) - an examination after eight semesters that will only be counted if the student passes it and which decreases the overall study period.

\section{Description of the Hanse Law School Program}

The Hanse Law School (HLS) was created by the cooperation of the Carl von Ossietzky University Oldenburg (D), the University of Bremen (D) and the Rijksuniversiteit Groningen (NL). The founders of the programs ${ }^{16}$ wished to create a genuinely European (and therefore multilingual) law study, one that went beyond the ordinary Staatsexam and that made use of the method of legal comparison. ${ }^{17}$ Their approach was, amongst others, inspired by the law program at McGill University, where a lot of weight is given to the positive effects of comparative law studies. ${ }^{18}$ Despite a considerable amount of resistance from the conservative German legal world (including from within the University of Bremen), the 'Zentrale Evaluations- und Akkreditierungsagentur' (Central Evaluations and Accreditations Office), Hanover - the central accreditation agency for Lower Saxony accepted their proposals and fully accredited the programs as 'veritable models of European legal studies. ${ }^{19}$

The study consists of a Bachelors and a Masters phase. ${ }^{20}$ While the Bachelors program (European and Comparative Law) takes four years, the Masters is a one-year-program. ${ }^{21}$ Participation in the program is restricted to 25 students. ${ }^{22}$ Half of these students are

\footnotetext{
${ }^{16}$ In particular, Prof. Dr. Lorenz Böllinger, Prof. Dr. Gert Brüggemeier, Prof. Dr. Hagen Lichtenberg, Prof. Dr. Erich Roeper and Prof. Dr. Dian Schefold (University of Bremen), Prof. Dr. Dagmar Schiek and Prof. Dr. Dr. h.c. Götz Frank (University of Oldenburg) and Prof. Dr. Damiaan Meuwissen, Prof. Dr. Dick Lubach and Berend Vis (University of Groningen).

17 Peter Rott, Die Hanse Law School - Vorreiter mit Zukunft?, in: René de Groot/André Janssen (Hrsg.), FESTSCHRIFT ZUM 60-JÄHRIGEN BESTEHEN DER DEUTSCH-NIEDERLÄNDISCHEN JURISTENKONFERENZ, forthComing 2009, 1. See, as to the reasons for the establishment of the HLS, also 'HLS Cahiers', Nr. 2 Methodology and its applications/La méthodologie et son application published by Rijksuniversiteit Groningen (2001).

${ }^{18}$ Information provided by Tim Thorsten Schwithal, coordinator HLS (University of Oldenburg).

${ }^{19}$ See, ZeVA, Hannover, Akkreditierungsbericht, 2006.

${ }^{20}$ See, infra, note 46 .

${ }^{21}$ Please note: The structure of the program has been exposed to changes over the last years in terms of study time and content. The most radical change has been the expansion of the Bachelor phase from 3 to 4 years in 2006. For the purpose of this paper the current study guidelines shall be described.

22 See, Ordnung über besondere Zugangsvoraussetzungen für den internationalen Bachelorstudiengang 'Comparative and European Law' der Hanse Law School an der Carl von Ossietzky Universität Oldenburg und der Universität Bremen (Guidelines on the admission criteria). In 2008, for the first time, 35 students were accepted
} 
selected on the basis of high school grades, with the average admission grade after 3 cycles being 1.6 (an -A grade). ${ }^{23}$ The rest of the places are allocated on the basis of a personal 30 minute interview. All students are tested on their English language skills prior to admission. ${ }^{24}$ The small enrolment leads to a very interactive atmosphere in the lectures, and low drop-out rates. ${ }^{25}$ Furthermore, every student is allocated an individual mentor from the university staff to guide the student's studies.

The program is primarily located in Oldenburg and in Bremen, however two semesters in the Bachelors and one semester in the Masters phase needs to be spent abroad, preferably at the partner University in Groningen. Students are prepared for their stay in the Netherlands from the first semester, with language courses, references to Dutch law in the lectures and the establishment of contact with Professors from the University of Groningen in team teachings with German professors. ${ }^{26}$ In addition to a focus on Dutch law, in keeping with the comparative approach of the program, core aspects of English Common Law are also taught. The language of instruction is approximately half in English, half in German, with an additional course in English legal terminology integrated into the program.

The curriculum is strongly focused on comparative law. The skills for approaching this discipline are taught in the first year and the theme continues throughout all further courses. This emphasis on comparative law is reflected in the opportunities for every student to study abroad, and these possibilities are not restricted to the Netherlands, but also include a range of other European universities, such as Sheffield, Madrid, Geneva, Lund etc. $^{27}$ A deeper understanding of the comparative process emerges during the exchange semesters, and students are also expected to select a comparative law topic for their Bachelors and Masters theses. The second focus of the curriculum is European Law, which forms a substantial part of the curriculum, including an obligatory moot on European Law in the second year of the Bachelors program. However, despite the alternative foci of the program, German law is not neglected; the program covers the same

with a view to increasing the number of students that take up Masters study at the HLS. So far, only in-house students could fulfil the admission criteria for the Masters program.

\footnotetext{
${ }^{23}$ See, supra, note 12.

${ }^{24}$ The requirement can be fulfilled by a TOEFL (Test of English as a Foreign Language) test with a minimum of 79 points (Internet-based Test) or an equivalent test, e.g. IELTS. (Requirement: Band 6).

${ }^{25}$ The reverse side of the coin is that this mentoring requires a lot of resources. However, exams etc. that have to be passed in different modules could be combined and merged and the workload for the university staff could be reduced.

${ }^{26}$ Team teaching means that a German and a Dutch Professor lecture together about the same legal topic and illustrate the differences and similarities in approaches in the two legal traditions.

${ }^{27}$ Lately also non-European universities, such as Melbourne and Calcutta.
} 
topics as the traditional Staatsexamen (state examination), with the exception of family and inheritance law, but simply from a comparative perspective.

Further, the Hanse Law School programs are not only concerned with traditional law subjects. Students are additionally obliged to follow three modules of economics and, since 2008, three political science modules which can be selected from a wide range of topics offered by the curricula of other faculties at the university. ${ }^{28}$ The program also caters to the practical side of law by requiring students to undergo an internship of 14 weeks as part of the Masters program. ${ }^{29}$ These internships can be done in Germany or abroad and are intended to give students the opportunity to apply the knowledge gained in their studies thus far and to prepare the student for entry in the workforce. They also aim to enhance soft skills, such as communication, assertiveness or teamwork. Internships in law firms in border regions where different national laws are applied are encouraged. HLS also leaves room for innovation and puts emphasis on extra-curricular activities: in 2005 students of the HLS, for example, founded the Hanse Law Review - an e-journal on European, International and Comparative Law, with two yearly publications. ${ }^{30}$

Examinations take place over the course of the semester, with each exam constituting an increasing percentage of the final grade. This places a distinctly less heavy burden on students than the final examination in traditional law programs.

The qualifications students gain from this program depends to a certain extent on their choices during the program. Completion of the program will not qualify students for the German Rechtsreferendariat and provide access to the traditional legal professions (e.g. judge, public prosecutor or barrister/solicitor ${ }^{31}$ ) as do the traditional legal education and Staatsexamen. However, where students opt to spend all their semesters abroad in the Netherlands, they can, in addition to the normal course load, take effectus civilis courses. Should they pass the full effectus civilis course complement in Dutch, they will be awarded a Masters degree that grants access to the professional Bar in the Netherlands. ${ }^{32}$ Students with effectus civilis can be admitted to the 3-year professional practical training that precedes admission to the Dutch bar. By qualifying as a lawyer in another EU Member State, it is possible to return to Germany (or move to any other Member State) to practice

\footnotetext{
28 See, section 4 (2) Examination Regulations, available at: http://www.hanse-law-school.de/, last accessed, 21 May 2009.

${ }^{29}$ See, section 4 (6) Examination Regulations and generally: Internship Regulations. Aims of the internship are listed in para. 2 of this regulation.

${ }^{30}$ See, HANSE LAW REVIEW, available at: http://www.hanselawreview.org, last accessed, 20 May 2009.

${ }^{31}$ In Germany there is only one profession: Rechtsanwalt.

${ }^{32}$ Those students that spend one semester of their Masters degree, but not necessarily their Bachelor degree, in Groningen receive a German-Dutch double Masters degree.
} 
within the ambit of the European right of establishment. ${ }^{33}$ The right of establishment is one of the so-called 'fundamental freedoms' that form part of the substantive law of the European Union. ${ }^{34}$ With the ongoing integration process of the EU the fundamental freedoms are crucial in that they not only regulate the flow of goods, capital, but also the movement of workers, students, service providers, and they create the possibility to establish a business in another Member State. Also, national laws that prevented the carrying out of these activities by lawyers have been gradually abolished. ${ }^{35}$ While a graduate who has successfully qualified as an 'advocaat ${ }^{36}$ in the Netherlands ${ }^{37}$ can immediately work under this title everywhere in the EU, he or she will have to undergo another 3 years of practical time in the new Member State working in the domestic legal system in order to be able to practice under a country's local title. ${ }^{38}$ This rule acknowledges that the differences between national legal orders requires a lawyer to have some experience in the applicable domestic legal system before, for example, a lawyer trained in Spanish law can give reliable advice on Greek law.

A number of HLS graduates have taken advantage of the free movement possibilities and that are currently advocaat stagiair - thus in the practical training - in the Netherlands. Once they have completed their training, it will be possible for them to be admitted to the Referendardienst without completion of the First State Exam. Instead, they will need to pass an equality exam (Gleichwertigkeitsprüfung). ${ }^{39}$ A number of Bachelors graduates have gone to the UK and have undertaken a Conversion Course (GDL), and then a Legal Practice Course (LPC) - each lasting 1 year - to qualify there as a solicitor. ${ }^{40}$

\footnotetext{
${ }^{33}$ For Germany, see, sections 2, 11 EuRAG - Gesetz über die Tätigkeit europäischer Rechtsanwälte in Deutschland (Law regulating the activity of European lawyers in Germany), available at: http://www.brak.de/seiten/pdf/ EuRAG.pdf, last accessed, 21 May, 2009.

${ }^{34}$ The four fundamental freedoms are the free movement of goods; the free movement of persons (and citizenship), including free movement of workers, and freedom of establishment; the free movement of services; and the free movement of capital.

${ }^{35}$ For the evolution of the free movement of professionals in particular see supra, note 8.

${ }^{36}$ The Dutch term for lawyer.

${ }^{37}$ The same is true for a full legal qualification in any other European Member State.

${ }^{38}$ See, supra, note 34, Art. 11

${ }^{39}$ This is set out in 112 a DRig (Deutsches Richtergesetz - The German Judiciary Act) and to a certain extent divergent in the different Länder. The first graduate will undertake this exam in July 2009. It follows particularly from the ECJ case, C-313/01, Christine Morgenbesser v. Consiglio dell' Ordine degli avvocati di Genova, 2003 E.C.R. I-13467 and Lubina v. Land Nordrhein-Westfalen AZ 10 K 7279/04 before the National German Administrative court in Düsseldorf,. See, for an overview, supra, note 8.

${ }^{40}$ As these courses are very expensive it is advisable to organize a training contract with a law firm and have them pay the expenses. Alternative ways via other European Member States can be explored. The Civil Effect will, however, always be advantageous.
} 
This is followed by a 2-year practical training similar to the Referendariat. In line with the right of establishment, this can also lead the HLS graduates back to Germany should they so choose.

\section{Where Are We Now?}

The Hanse Law School has identified the main contemporary challenges facing law students as being the Europeanisation of law and the greater mobility of lawyers and trains students to meet these challenges. But, does the HLS program actually give students the skills and knowledge that employers are looking for?

Among Bachelors graduates, ${ }^{41} 90 \%$ have opted for further study in a Masters program. Most have done so immediately following their undergraduate degree, while approximately half choose to continue their education with the HLS. The rest study at universities across a range of European countries. ${ }^{42}$ Some graduates successfully sought paid employment following their Bachelors degree. ${ }^{43}$ However, there was a strong feeling among students that finding a job on the basis of a Bachelors qualification was easier outside Germany, although (at least) one student has found permanent employment in a German law firm on the basis of the Bachelors. ${ }^{44}$

LL.M. graduates, however, have streamed into the labour market. About a third of graduates work in the private sector, mainly in consultancies $(29 \%)$, while more than a quarter opting to work for international organisations and associations (26\%). Another quarter (25\%), have taken up Ph.D. research. In-house consulting in large law firms, such as Lovells, Sherman \& Sterling, Linklaters, Latham \& Watkins, Lampe \& Schwartze, Duijnstee van der Wilk Advocaten, KienhuisHoving Advocaten en Notarissen, accounted for $16 \%$ of graduates; ${ }^{45}$ an increase from the first to the second year. Only in a handful of individual cases did searching for a job take longer than half a year. In the case of the students that

\footnotetext{
${ }^{41}$ The drop-out rate in the HLS study is less than $10 \%$.

${ }^{42}$ See, supra, note 12 .

${ }^{43}$ See e.g. Franz Christian Ebert, available at: http://www.spiegel.de/unispiegel/studium/0,1518,549857,00.html, last accessed, 20 May 2009. Other examples include: EDCTP (European \& Developing Countries Clinical Trials Partnership), The Hague or the European Design and Trademark Office, Alicante.

${ }^{44}$ See, for some examples of experiences of students and alumni brochure, 'Hanse Law School', by Hanse Law School, Oldenburg, forthcoming 2009, 17.

${ }^{45}$ See, University Calendar 2008/9, available at: http://www.hanse-law-school.de/, last accessed, 21 May 2009, p. 5.
} 
graduated in 2006 (LL.B.), of which approximately 50\% also completed the HLS LL.M. in 2007,7 out of 20 of these graduates found work in Germany. ${ }^{46}$

It would thus appear from these figures that HLS prepares its students very well for research, particularly if country comparisons form part of it. Several graduates have gained PhD positions and do research with a view to improving policy-making in Brussels for European directives and regulations, practically applying the techniques of legal comparisons that they have learned. HLS students found it striking that when studying Masters program elsewhere, they found it much easier to write papers in a foreign language than it was for Staatsexam students, particularly with English legal terminology.

The Staatsexam, whose structure was sketched above, is the subject of a lot of general criticism, ranging from the long study time -partly mitigated by the Freiversuch - to the concept of the Einheitsjurist that puts too high a burden on students whose aim it is not to become a judge. Common problems of the university system, such as crowded lectures and anonymity, also detract from the quality of study. ${ }^{47}$ The First State Exam and the preparation period are regarded as very tough, especially psychologically, and only about half of students beginning university studies in law successfully take the First State Exam. ${ }^{48}$ The most frequent grade received is 'sufficient' (ausreichend - 4 points). ${ }^{49}$ The grading system is another point of criticism. ${ }^{50}$ Only with a 'fully satisfactory' (vollbefriedigend - 9 points) is the job market, e.g. the possibility to become judge, really open. ${ }^{51}$ The need for reform is undisputed.

\footnotetext{
${ }^{46}$ Four former HLS students of that year have not yet entered the labour market because they merged the Staatsexam study.

${ }^{47}$ See, supra, note 13, Keilmann at 297: "First and second year courses with 400 or 500 students are not at all rare."

48 See, statistics by the Federal Ministry of Justice, available at: http://www.bmbf.de/pub/studien abbruchstudie_2002.pdf, last accessed, 21 May 2009.

${ }^{49}$ See, supra, note 15.

${ }^{50}$ Even though the range of grades that can be achieved goes from 1 to 18 , the slogans are ' 4 wins' and ' 9 is magic'.

${ }^{51}$ See, supra, note 15, in 2006 this grade was reached by $12.2 \%$ in the First State Exam and $14.2 \%$ in the Second State Exam. Depending on where you want to apply the grade of the first or the second state exam or even single grades from civil, public or criminal law will be decisive. It is, furthermore, interesting that despite alleging that the exam is organized at the federal level, the exams of students in one State are downgraded when applying for posts in another.
} 
Recently it was decided that students can be examined during their studies for the equivalent of $30 \%$ of the final mark. The resistance towards reforms - generally and in the ambit of the Bologna process - is, however, very high and not without reason; the Staatsexam was recently called a 'dinosaur' by a well-known German magazine. ${ }^{52}$

Despite mitigating some of the criticised aspects of the Staatsexam for the students of the HLS there is a clear downside to participation in such an innovative program, particularly within Germany. Obviously $\mathrm{HLS}^{53}$ graduates are not fully qualified German lawyers and therefore they are restricted in their post-study choice of work. This restriction is made clear to prospective applicants and that training for the Staatsexam is clearly not the objective of the studies is reflected in the curriculum - considerably less importance is given to procedural law. Should a student's aim be to work in a traditional law firm, graduates with a HLS degree working in such an environment would currently advise them to undertake an ordinary law degree. Otherwise, due to the unresolved status of HLS graduates, he or she is likely to be paid considerably less than Staatsexamen graduates. ${ }^{54}$ HLS graduates, however, also report that after proving themselves to the law firm, wages regularly increase and the tasks become more challenging. It is typical of Germany's academic legal world to be very suspicious of experiences acquired abroad. For example, fully qualified German lawyers with a PhD from another country also report discrimination in the German job market. The value of an additional LL.M. from an English speaking country, that many German lawyers opt for, is often seen by a German law firm as providing additional language skills, but it is hardly valued for the comparative legal insights that might be gained. ${ }^{55}$

\section{E. Conclusion}

Contrary to all affirmative announcements made in the context of the Bologna declaration, faculties of law, of medicine and of engineering in Germany are highly resistant to reforms of their studies. ${ }^{56} \mathrm{~A}$ recent announcement in late 2008 smoothed ruffled feathers and

52 See, Von Jochen Schönmann, Angriff auf den Dinosaurier, SPIEGEL (20 March 2008), available at: http://www.spiegel.de/unispiegel/studium/0,1518,542687,00.html, last accessed 20 May 2009.

${ }^{53}$ It is here referred to the normal way and not to special qualifications like the effectus civilis.

${ }^{54}$ Some students, who during their studies felt that they want to become lawyers often used the chance to merge the Staatsexam after 3 years of HLS. Nearly all their courses were recognised, and they were able to continue with their studies having an LL.B. up their sleeve already.

${ }^{55}$ This became clear in exchange with colleagues during internships.

56 'Medizin ,light': der Bachelor kommt', DER WESTEN (15 October 2008), available at: http://www.derwesten.de/ nachrichten/nachrichten/campus-und-karriere/campus/2008/10/15/news-83460406/detail.html [this link does not work -TW], last accessed, 11 May 2009, or 'Professoren-Lobby springt auf die Bremse', SPIEGEL (5 September 
declared that no reforms can be expected in legal training for the next 3 years. ${ }^{57}$ This is frustrating for all those brave students that opted for a Bachelors or Masters study in law as the lack of reform leaves them in a vacuum. ${ }^{58}$ However, HLS graduates have adapted to this resistance in Germany and have, nonetheless, successfully conquered the labour market - even if often from outside of Germany. Furthermore, students achieve this in a much shorter period of study.

The aim of this paper, in contrasting the two systems, was not necessarily to suggest that the HLS study can substitute the Staatsexam (currently the way to become a lawyer in Germany is more burdensome via the HLS than the ordinary program). Rather, this paper demonstrated that a truly transnational program that does not neglect German Law can deliver graduates that are sought after in the job market, and more than this, perhaps suggest a possible avenue for how current German legal education could be reformed in the context of internationalisation. HLS is a very successful niche product and as such unique in Germany's academic world.

The advantages of a HLS graduate are clear: knowledge of various legal systems and traditions, familiarity with the techniques of legal comparison, language skills, intercultural experience and, derived from broad cultural experience, the ability to think outside the box. The fact that the students study different legal orders and the multilevel system of EC and national law at the same time and in several languages speaks for itself. Last, but not least, graduates are clearly not risk-averse as they have dared to study something with a rather unclear future and under a weight of criticism from traditional legal scholars and employers.

We, however, see quite clearly that, in contrast to many other European countries, Germany is not able to recognise the true value of these graduates; as a consequence, young graduates with a demonstrated potential who are trained for participation in an internationalising legal world feel forced to leave the country. Many will not return and in an Europeanising legal market, it therefore seems reasonable to suggest that Germany will need to work harder to retain its homegrown talent.

2008), available at: http://www.spiegel.de/unispiegel/studium/0,1518,576339,00.html, last accessed, 21 May 2009.

57 'Drei Jahre Pause: Bachelor und Master fuer Juristen', AZUR (25 November 2009), available at: http://www.azuronline.de/azhtml/stud_intro.html, last accessed, 21 May 2009.

${ }^{58}$ See, supra, note 40 . It is in particular referred to students that do not acquire special qualifications like the effectus civilis in the Netherlands. A possible solution lies in the ECJ case; see also, supra, note 8. 
